\title{
Measurement and evaluation of emergency lighting equipped with LED
}

\begin{abstract}
The issue of emergency lighting is quite complicated and meeting all standard requirements are often very complex. Rapid development in the field of LED light sources has brought new possibilities in the design of emergency lighting. In particular, LED has a higher power output in comparison to conventional light sources used in emergency lighting and also the size of LED is smaller. Another advantage is the possibility of optimal routing of LED diodes by means of suitable optics depending on the areas and the type of emergency lighting. Measurements were performed on a prototype of autonomous emergency lamp, which does not use a conventional battery as a source of energy, but super-capacitor. Especially from the perspective of a long lifespan, its fast charging and reducing of dependence on temperature, the super-capacitor seems like very reliable replacement of batteries previously used.
\end{abstract}

Key words: super-capacitor, emergency lighting, power LED diode.

\section{Introdaction}

The main theme of this article is to evaluate selected properties of the super-capacitor, and its use in combination with the power LED in the field of emergency lighting. A new type of autonomous emergency light which is powered by a super-capacitor was designed at the Technical University of Ostrava (VSB). The norm CSN EN1838 divides emergency lighting into two main groups, emergency exit lights and spare lights. Prototype of emergency light is particularly suitable for emergency exit areas, without the possibility of central power and with the assumption of temperature fluctuations and complicated maintenance. Super-capacitor, unlike commonly used batteries can be operated maintenance free and due to absence of memory effect has significantly longer median lifespan than conventional batteries. Unlike conventional batteries, which are temperature dependent and therefore not suitable for installation in areas with low temperatures, super-capacitor is temperature independent and the operation at low temperatures even positively influences its parameters. Combination of a power LED diode and a super-capacitor in emergency lighting therefore seem appropriate and perspective possibility for achieving longer lifespan of the whole system and also the achievement of cost savings associated with maintenance and replacement of batteries and light sources. For the objective assessment of these properties was the prototype of the emergency light subjected to several electrical measurements $[1,2]$.

\section{The comparison of basic performance-technical parameters of electric energy sources}

The comparison of conventional and experimental sources of electricity that are used in all applications with the need for backup power, is shown in the Chart 1. For reasons of source comparison with other sources than chemical method of electricity saving are in Chart 1. displayed also parameters of classic electrolytic capacitor. Currently, the most widely used groups of backup sources in the field of electricity supply in emergency lights include $\mathrm{NiCd}, \mathrm{NiMH}$ and $\mathrm{Pb}$ batteries. Super-capacitor is the most effective source of energy of the new generation, thanks to its high efficiency of charging and discharging process, and the long lifespan (number of charging cycles). Their power output is 5 to 10 times greater than the power output of conventional batteries in emergency lights and are characterized by a significantly shorter charging and discharging time. When emergency lights are powered by a super-capacitor, the discharge time depends on the overall efficiency of the power transfer from the backup source to the light source.
This means that we have to also count the efficiency of the transformer or PWM. In comparison to a classic conventional electrolytic capacitor, the super-capacitor provides a far greater range of measured energy values [3, 4].

Tab 1. Performance-technical parameters of electrical energy sources (source: data sheets batteries)

\begin{tabular}{|c|c|c|c|c|c|}
\hline & $\begin{array}{c}\text { NiCd } \\
\text { battery }\end{array}$ & $\begin{array}{c}\text { NiMH } \\
\text { battery }\end{array}$ & $\begin{array}{c}\text { Pb } \\
\text { battery }\end{array}$ & Capacitor & $\begin{array}{c}\text { Super - } \\
\text { capacitor }\end{array}$ \\
\hline $\begin{array}{c}\text { Charging } \\
\text { time [hod,s] }\end{array}$ & $1-5 \mathrm{~h}$ & $1-5 \mathrm{~h}$ & $1-5 \mathrm{~h}$ & $10^{-3}-10^{-6} \mathrm{~s}$ & $0,3-30 \mathrm{~s}$ \\
\hline $\begin{array}{c}\text { Discharging } \\
\text { time } \\
\text { [hod, s] }\end{array}$ & $1-2 \mathrm{~h}$ & $2-4 \mathrm{~h}$ & $0,3-3 \mathrm{~h}$ & $10^{-3}-10^{-6} \mathrm{~s}$ & $0,3-30 \mathrm{~s}$ \\
\hline $\begin{array}{c}\text { Specific } \\
\text { energy } \\
\text { [Wh/kg] }\end{array}$ & $40-60$ & $60-80$ & $30-40$ & $<0,1$ & $1-10$ \\
\hline $\begin{array}{c}\text { Specific } \\
\text { power } \\
\text { [W/kg] }\end{array}$ & $<1500$ & $<3000$ & $<1000$ & $<100000$ & $<10000$ \\
\hline $\begin{array}{c}\text { Lifetime } \\
\text { [cycles] }\end{array}$ & $500-1$ & $1000-$ & 1000 & $>500000$ & $>1000000$ \\
\hline $\begin{array}{c}\text { Efficiency } \\
{[\%]}\end{array}$ & $>80$ & $>80$ & $70-85$ & $>95$ & $85-98$ \\
\hline
\end{tabular}

\section{Super-capacitor application in autonomous emergency} light

Based on the study and calculation, which is shown below, the combination of power LED and a super-capacitor becomes by its parameters an adequate successor for conventional autonomous emergency lights equipped with a classic battery and a fluorescent lamp. Compared to classic conventional batteries, super-capacitor offers many advantages, which can be used in the field of emergency lighting. The size of the necessary capacity for autonomous power supply of emergency light is derived from its discharge characteristics. The prototype of the emergency light that we tested is equipped with a power LED diode of type: HPB8-49KWGB 1W 125lm and DC/DC converter LTC3490.

Assuming that the light source is powered by a constant current and voltage on the supercapacitor will decrease approximately linearly with the current size of the current drawn by the drive. According to the size of its capacity, the light can be used in various areas where requirements are different regarding the lighting time. Specifically, we tested a prototype which has been developed for emergency escape lighting applications, where demand for lighting time is 1 hour. For this time of autonomous operation was used the prototype MAXWELL BCAP2000 super-capacitor. 
Theoretical verification of super-capacitor capacity for the emergency light prototype

Note: The values for the calculation are taken from data sheets of converters and LED diode described above.

The minimum operating voltage of LTC3490 converter:

$$
U_{\text {min }}=0,9 \mathrm{~V}
$$

The initial voltage of maximally charged super-capacitor MAXWELL $2000 \mathrm{~F}$ :

$$
U_{0}=2,7 \mathrm{~V}
$$

Permissible voltage reduction of the super-capacitor:

$$
\begin{aligned}
& \Delta U=U_{0}-U_{\min }[V] \\
& \Delta U=2,7-0,9=1,8 \mathrm{~V}
\end{aligned}
$$

Consumed constant input by a LED diode:

$$
P_{1}=1 W
$$

The average efficiency of DC/DC LTC3490 converter:

$$
\eta_{D V R}=0,8
$$

Required lighting time (norm CSN 1838 Emergency lighting - areas with lighting period of 1 hour):

$$
t_{s}=3600 \mathrm{~s}
$$

The factor of super-capacitor aging (decline of capacity in 10 years):

$$
k=0,8
$$

The average withdraw of current by a converter:

(2) $I_{\text {avg }}=\frac{I_{\max }+I_{\min }}{2}=\frac{\frac{P_{1}}{U_{\min } \cdot \eta_{D V R}}+\frac{P_{1}}{U_{0} \cdot \eta_{D V R}}}{2}=[A]$

$$
I_{\text {avg }}=\frac{\frac{1}{0,9 \cdot 0,8}+\frac{1}{2,7 \cdot 0,8}}{2}=0,926 \mathrm{~A}
$$

In the calculation we do not count the voltage drop component on the internal resistance. Because the current will decrease linearly, we will replace the instantaneous current with average current $\left(l_{\text {avg }}\right)$.

$$
\begin{aligned}
& C=\frac{I_{a v g} \cdot t}{\Delta U}=[F] \\
& C=\frac{0,926 \cdot 3600}{1,8}=1852 \mathrm{~F}
\end{aligned}
$$

The projected lifespan of the super-capacitor:

$$
\begin{aligned}
& C_{s}=\frac{C}{k}=[F] \\
& C_{s}=\frac{1852}{0,8}=2315 \mathrm{~F}
\end{aligned}
$$

The above calculation shows that a super-capacitor is fully applicable for powering of autonomous emergency lights. For the use of autonomous emergency lights in areas where is a requirement for lighting of one hour or less, the super-capacitor with a capacity of $2315 \mathrm{~F}$ is fully sufficient. While the indicative calculation shows that for everyday use, it is necessary to use a capacity of more than $2315 \mathrm{~F}$ for prototype of autonomous emergency light, it was chosen a super-capacitor with the closest (lowest) value of of 2000 F capacity for testing (cost and dimensional reasons). Measuring of the characteristics of autonomous emergency light. Above specified autonomous emergency light has been subjected to several electrical measurements, and the goal was to demonstrate its benefits and efficiency. The light is equipped with a power LED diode with a power input of $1 \mathrm{~W}$, which has relatively high measuring power, up to $125 \mathrm{~lm} / \mathrm{W}$ on average and color of chrome temperature of $6000 \mathrm{~K}$. The light prototype is powered by a super-capacitor with capacity of $2000 \mathrm{~F}$ with a working voltage output of 2.7 $\mathrm{V}[4]$.

\section{Self-discharge measurement of the super-capacitor}

Self-discharge is a phenomenon manifesting the loss of discharge of electric energy source even under the condition that nothing is connected to the source. This process negatively affects the life of the super-capacitor and the life of other accumulator batteries. The progress of self-discharge was measured in order to find out the behavior of the super-capacitor during prolonged disconnection at different temperatures. A super-capacitor with capacity of $2000 \mathrm{~F}$ was measured. This super-capacitor was charged using sources VOLTCRAFT VSP 1410 with 2.7 V. The process of self-discharge of the super-capacitor was recorded at four different temperatures $\left(-15^{\circ} \mathrm{C}, 0^{\circ} \mathrm{C}\right.$, $23^{\circ} \mathrm{C}, 50^{\circ} \mathrm{C}$ ). To achieve the desired environmental temperature, there was used a climatic chamber. The value of energy when the super-capacitor $2000 \mathrm{~F}$ is fully charged with $2.7 \mathrm{~V}$ operating voltage is $2.03 \mathrm{Wh}$. During the selfdischarge the super-capacitor voltage was monitored, and it was gradually decreasing. The power was recorded using a special measuring card with a modified input for low voltage. The measured values were processed by computer in Excel program. The graph below shows the time progress of the voltage on the super-capacitor during 1 hour. Chart 2. shows voltage drops percentages and energies for one hour at various temperatures [2, 4].

Tab 2. Percentage drop of power and energy

\begin{tabular}{|c|c|c|}
\hline Temperature & Voltage drop & Enrgy drop \\
\hline$-15^{\circ} \mathrm{C}$ & $1,63 \%$ & $3,23 \%$ \\
\hline $0^{\circ} \mathrm{C}$ & $1,81 \%$ & $3,59 \%$ \\
\hline $23^{\circ} \mathrm{C}$ & $9,93 \%$ & $18,87 \%$ \\
\hline $50^{\circ} \mathrm{C}$ & $10,67 \%$ & $20,19 \%$ \\
\hline
\end{tabular}




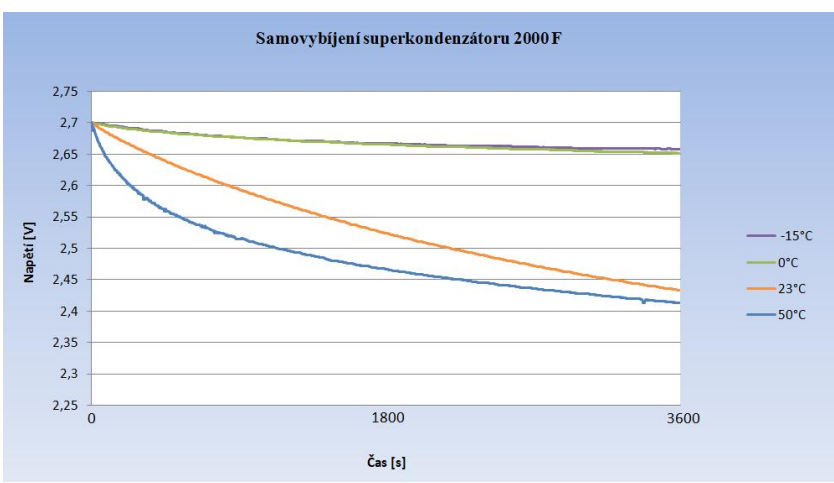

Fig.1. Graph of voltage during the self-discharge

The above graph shows that the temperature slightly influences the process of self-discharge. Generally, the lower the working or storage temperature, the lower the drop process of the voltage that depends on the temperature. This characteristics of the super-capacitor makes it suitable for use in areas where is consistently low temperature, where the use of conventional battery would be complicated (loss of capacity and decrease of average lifespan). All curves have an exponential character with the most marked decrease at the beginning of self-discharge. Higher operating temperatures result in rapid progress of self-discharge. Autonomous emergency light is powered by electrical power continuously using electrical circuits and emergency mode is activated immediately upon failure of the normal lighting. This means that the light is always in a state of maximum charge. Electronic circuits automatically start to recharge the super-capacitor at a higher voltage drop, just as they are able to shut down the charging of the super-capacitor when reaching the limit of the nominal charge. However, it must be remembered that the selfdischarge affects the number of cycles and therefore the lifetime of the super-capacitor [4]

\section{The lighting time of emergency light}

For verification of maximum lighting time was used the same procedure and the same super-capacitor as with measurement of self-discharge with the difference that the super-capacitor powered the autonomous emergency light. There were recorded two values of voltage, the voltage on the super-capacitor and the output voltage of the convertor. Integrated circuit automatically controls and regulates the output of current and voltage. Since the voltage of the super-capacitor during discharge decreases from the maximum value $(2.7 \mathrm{~V})$ to zero, it was used, for the stabilization parameters on the LED, a DC/DC converter which has the job to stabilize the output of current to a constant value. The amount of current for the LED diode and super-capacitor were not measured because of the voltage drop, which originated at measuring sides, contacts and wirings.

Power $1 \mathrm{~W}$ LED diode is powered by a DC/DC converter LTC3490, which supplies it with constant current at gradually decreasing power of the super-capacitor up to the limit at which a DC/DC converter shuts off. Measured voltage values, at which the $\mathrm{DC} / \mathrm{DC}$ converter shuts off, were for each temperature levels approximately the same and ranged from $0.608 \mathrm{~V}$ at $-15^{\circ} \mathrm{C}$ and the value of 0.664 $\mathrm{V}$ at $50^{\circ} \mathrm{C}$. Measured values of lighting time and voltage limits for each temperature are shown in the Chart 3 . and on Figure 2.
Tab.3. The measured values at different temperatures

\begin{tabular}{|c|c|c|c|c|}
\hline & $-15^{\circ} \mathbf{C}$ & $0^{\circ} \mathbf{C}$ & $\mathbf{2 3}^{\circ} \mathbf{C}$ & $5^{\circ} \mathbf{C}$ \\
\hline $\begin{array}{c}\text { Limiting value } \\
\text { of voltage }\end{array}$ & $0,608 \mathrm{~V}$ & $0,622 \mathrm{~V}$ & $0,626 \mathrm{~V}$ & $0,664 \mathrm{~V}$ \\
\hline Lighting time & $6090 \mathrm{~s}$ & $6018 \mathrm{~s}$ & $5817 \mathrm{~s}$ & $5729 \mathrm{~s}$ \\
\hline
\end{tabular}

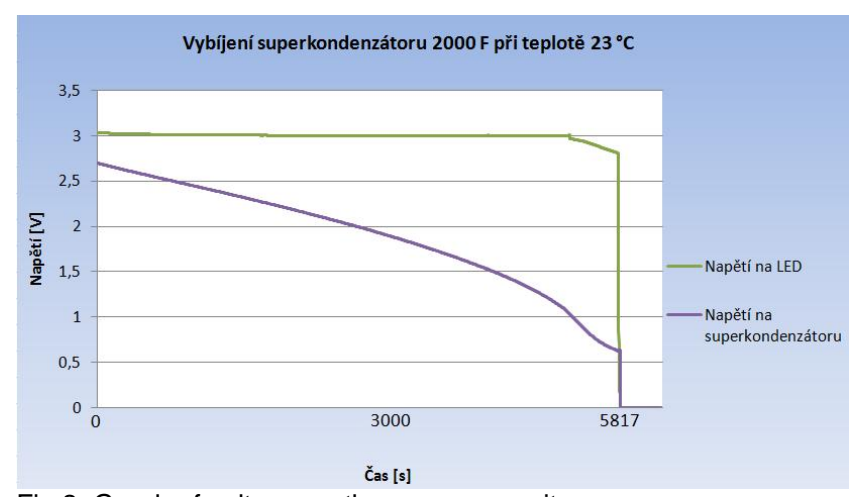

Fig.2. Graph of voltage on the super-capacitor

By measuring of the discharging process of the supercapacitor with a capacity of $2000 \mathrm{~F}$ and a maximum working voltage of $2.7 \mathrm{~V}$ it was found that it provides enough energy to power the autonomous emergency light during one hour. With all measured temperatures was the time of lighting significantly greater than 1 hour (see Chart 3.) from where you can see that the prototype of the autonomous emergency light equipped with 1W LED diode and a supercapacitor with capacity of $2000 \mathrm{~F}$ is fully operational for emergency lighting applications. Measured values of lighting time do not correspond with the theoretical calculation, which is presented in the theoretical part of the article, and for this reason, the convertor was able to work at a lower voltage than specified in the catalog $(0.9 \mathrm{~V}$ compared to about $0.620 \mathrm{~V}$ ). Thanks to this difference, the super-capacitor managed to produce a significantly more of usable energy. Using LED diode with a higher input, or the extension of lighting lifespan would significantly affect the financial requirements of the proposal because it would be necessary to use a super-capacitor with higher capacity for securing the needed energy [4].

\section{Conclusion}

These measurements showed that the new prototype of autonomous emergency light that is equipped with LED diode and during emergency mode is powered by a supercapacitor, meets all the requirements to become an adequate successor of previously used autonomous emergency lights. Compared to classic emergency lights it provides many benefits, although at the expense of higher initial cost, which, during the lifetime of the lights will return in the form of maintenance costs savings and a slightly larger size of the accumulator part. The new type of emergency light is particularly suitable for areas where access to lights is complicated (high light levels) or in areas where may be low operating environmental temperature (outside, cooling facilities and the like).

\section{ACKNOWLEDGMENT}

This article was prepared with the support of the project " Transmission of control signals in lighting systems" SP2015/182, by institution of VSB-TU Ostrava. 


\section{REFERENCES}

[1] Dostál Carbol, Z., Novák, T., Hrbáč, R., Sokanský, K.: Supercapacitors as a power source for emergency lighting luminaires, EPE 2013, VŠB-TUO, Code: 104454

[2] Carbol, Z., Novák, T., Hrbáč, R., Sokanský, K.: Autonomous emergency LED luminaires powered by supercapacitor, Przeglad Elektrotechniczny, 2013, Pages 69-72, ISSN:00332097

[3] Pavelka, V., Rekuperační systém se superkondenzátorem. Praha, 3.3.2003. Závereční zpráva studijní etapy doktorského studia. České vysoké učení technické.

[4] Baleja, R., Aplikácia núdzových svietidiel vybavených superkondenzátorom, Diplomová práce, 2014, VŠB TU-O
Authors: prof. ing. Karel Sokanský, CSc., Vysoká škola báňská Technická univerzita Ostrava Fakulta elektrotechniky a informatiky, 17. Listopadu 15/2172, Czech Republic, e-mail: karel.sokansky@vsb.cz 